\title{
ZAČIATKY MODERNÉHO MESTSKÉHO PLÁNOVANIA V UHORSKU PRÍPAD BRATISLAVY A NOVÉHO SADU
}

\author{
HENRIETA M O R A V Č Í K O V Á - ÉVA L O V R A - LAURA \\ K R I Š T E K O V Á
}

\begin{abstract}
MORAVČÍKOVÁ, Henrieta - LOVRA, Éva - KRIŠTEKOVÁ, Laura. The beginnings of modern urban planning in the Kingdom of Hungary using the examples of Bratislava and Novi Sad. Historický časopis, 2019, 67,3 , pp. 467-480, Bratislava.

The principles of modern urban planning began to be applied in the Kingdom of Hungary in the second half of the 19th century. In most cases, the first regulation plans appeared around 1900, when these cities were experiencing dynamic growth. The ideas generated in the first plans for regulation and long-term development pre-determined the development of these cities and has determined their form until today. The study considers the principles and approaches applied in modern planning at the turn of the century. Using the example of two cities - Bratislava and Nový Sad - it analyses the key terms applied in expert discussion at the time, their use in territorial planning practice and the contribution of the notable Hungarian city planning expert Antal Palóczi to this discussion.

Key words: Planning. Regulation. Regulation plan. City. Bratislava. Nový Sad.

DOI: https://doi.org/10.31577/histcaso.2019.67.3.4
\end{abstract}

Obdobie medzi rokmi 1867 a 1918 predstavuje jednu z najproduktívnejších dôb plánovania a modernizácie miest v Uhorsku. Prestavba historických štruktúr a výstavba nových mestských častí pritom vrcholila na sklonku 19. a začiatkom 20. storočia. Spoločenské a hospodárske zmeny, ktoré podmienilo rakúsko-uhorské vyrovnanie v roku 1867, mierne naštartovali industrializáciu Uhorska aj premenu uhorských miest. Vývoj v uhorských mestách bol pritom priamo ovplyvnený aj zmenou paradigmy v oblasti plánovania miest. V tomto období vznikali nové typy zástavby, realizovali sa budovy nových typológií a vo všeobecnosti sa do zásad výstavby miest dostali myšlienky moderného plánovania, ako boli hygienické zásady, princípy zónovania a nové názory na dopravnú infraštruktúru. Na územie Uhorska prenikali európske trendy moderného urbanizmu s určitým oneskorením a v praktickom plánovaní a výstavbe miest sa uplatňovali len po- 
maly a s t'ažkost'ami. Napriek tomu uhorskí architekti a inžinieri sledovali tieto tendencie vel'mi pozorne, diskutovali o nich a aplikovali ich pri regulácii a plánovaní miest v Uhorsku.

Prvé regulačné plány vychádzali z inžinierskeho prístupu nemeckých urbanistov, ako bol Reinhard Baumeister a Joseph Stübben. Regulácia sa uplatňovala mechanicky, pravouhlá mriežka uličnej siete s mestskými blokmi a dopravné okruhy boli považované za základ plánovania a výstavby mesta. Tento prístup súčasne priniesol do uhorských miest členenie mesta na zóny v zmysle funkcie zástavby, ako aj dôraz na hygienické a sanitárne zásady. Zakrátko sa však stalo toto mechanické regulovanie mestskej zástavby terčom kritiky z radov odborníkov, ktorí tak vytvárali priestor na uplatnenie umeleckého prístupu k plánovaniu mesta v zmysle názorov viedenského architekta a urbanistu Camilla Sitteho. Taký spôsob narábania s mestskou štruktúrou možno sledovat' napríklad v práci Josipa Pospošila v Sarajeve, Antala Palócziho v Bratislave a v Novom Sade, Lajosa Ybla v Temešvári či Lajosa Lechnera v Szegede a v Budapešti. Moderné princípy plánovania mesta, rovnako ako základná typológia mestských priestorov (okruh, bulvár, promenáda, mestský park, záhradná štvrt' a pod.) sa stali spoločnou platformou pre formovanie miest v celom Rakúsko-Uhorsku. Tento spoločný urbanistický jazyk bol najlepšie čitatel’ný tam, kde sa plány realizovali v celej svojej zložitosti, ako to bolo v prípade Budapešti či Szegedu. Väčšina vtedajších plánov sa však uplatnila len čiastočne, respektíve v tak fragmentovanej podobe, že je dnes t'ažké ich identifikovat' v morfológii miest. Prispieva k tomu aj skutočnost', že po rozpade monarchie sa narušila kontinuita plánovania a v nástupníckych štátoch dochádzalo často $\mathrm{k}$ zámernému odmietaniu či ignorácii plánov z predchádzajúceho obdobia. Práve taká bola situácia aj v Prešporku a v Novom Sade. Nasledujúci text prináša výsledky aktuálnych výskumov, ktoré odhalili doteraz neznáme dokumenty týkajúce sa začiatkov moderného plánovania týchto dvoch miest.

Bratislava a Nový Sad sa dnes nachádzajú v dvoch samostatných štátoch. Niekol'ko storočí však boli súčast’ou jednej monarchie, čo podmienilo paralely v ich vývoji. Obe mestá spájajú aj podobné geografické danosti. Ležia na l’avom brehu rieky Dunaj, pričom kedysi v rámci monarchie predstavoval Nový Sad jej najjužnejšie a Bratislava najzápadnejšie situované král'ovské mesto. Morfológiu oboch miest výrazne ovplyvnila prítomnost' rieky a výbežkov Karpát, ktoré priamo alebo sprostredkovane determinovali aj štruktúru zástavby.

V polovici 19. storočia opísal Elek Fényes v Geografickom slovníku Uhorska Bratislavu ako „najstaršie, najkrajšie a najslávnejšie zo všetkých královských miest... Niet trhoviska či námestia, ktoré by si nezaslúžilo privlastok krásne, pre svoje rozmery či pravidelný tvar. Ulice sú široké a dlhé, čisté a zväčš vydláždené kameňom a tie hlavné dokonca granitovou dlažbou. Pri meste stojí na vyso- 
kom kopci hrad, ktorý čnie nad Dunaj s nádherným výhl'adom na zelené ostrovy Dunaja a okolitých ramien a na rakúske zalesnené kopce “. ${ }^{1}$ Nový Sad je v tom istom slovníku opísaný takto: „Aj ked’ mesto postavili bez väčsieho zmyslu pre poriadok, môže sa pochválit’ krásnymi domami, najmä Dunajská ulica sa môže pýsit’ svojimi dvojposchodovými budovami s bohatými obchodmi. "2

Nový Sad sa začal výraznejšie vyvíjat’ až v druhej polovici 19. storočia, pričom jeho pôvodné historické jadro ostalo nad’alej nezmenené. Prvé katastrálne zameranie mesta sa uskutočnilo v roku 1876 a na jeho základe pripravili v roku 1877 prvú katastrálnu mapu mesta, ktorá vyšla v roku $1880 .{ }^{3}$ Podobný vývoj bol aj v Bratislave, ktorá si tiež zachovala pôvodnú podobu historického jadra vrátane hradného kopca, zatial' čo nové štruktúry vznikali najmä na jej okraji. Situačnú mapu mesta v mierke 1:3 600 vyhotovilo technické oddelenie mesta pod vedením hlavného inžiniera Antona Sendleina v roku 1882 a možno ju považovat' za prvý podrobný plán zachytávajúci podobu Bratislavy. Roku 1894 vznikla prvá katastrálne mapa mesta $\mathrm{v}$ mierke 1:10 000. O tri roky neskôr v roku 1897 podrobná katastrálna mapa zobrazujúca jednotlivé parcely aj s číslami. Dynamický rast uhorských miest v 19. storočí si však vyžadoval nielen mapovanie existujúceho stavu, ale aj fungujúce nástroje plánovania a regulácie mestskej výstavby. Odborná diskusia na túto tému začala síce pomerne skoro po rakúsko-uhorskom vyrovnaní, avšak práve chýbajúca základná dokumentácia potrebná k regulácii spôsobila oneskorenie tohto procesu o niekol'ko desat'ročí.

V období rakúsko-uhorskej monarchie podliehali všetky stavebné aktivity vrátane zakladania nových štvrtí a ulíc či výstavby nových budov pod správu technického oddelenia mesta. O dôležitých investíciách však rozhodovala priamo mestská rada alebo uhorské ministerstvá. Rozhodnutia tak často odrážali individuálne preferencie a záujmy členov mestskej rady alebo ministerských úradníkov. V roku 1896 poverili technické oddelenie pod vedením Antona Sendleina prípravou plánu regulácie a rozvoja vtedajšieho Prešporku, ako aj revíziou Stavebného poriadku mesta. ${ }^{4}$ Mestská rada prerokúvala tento plán na zvláštnom zasadnutí v decembri 1898 a odporučila niekol'ko úprav, ktoré sa týkali najmä rozšírenia niektorých plánovaných ulíc. Pracovníci technického oddelenia tak pokračovali na príprave plánu. Jeho konečnou verziou je pravdepodobne plán z roku 1906 vyhotovený na podklade katastrálnej mapy z roku 1894, ktorý sa

1 FÉNYES, Elek. Magyarország geográfiai szótára. Pesten 1851. http://www.fszek.hu/digitdoc/fenyes/ [cit. 2019-05-04].

2 FÉNYES, ref. 1.

3 Arhiv Vojvodine Novi Sad, F. 419 69-70-73-74-77.

4 MORAVČÍKOVÁ, Henrieta - LOVRA, Éva - PASTOREKOVÁ, Laura. Červený alebo modrý? Začiatky moderného plánovania Bratislavy. In Architektúra \& urbanizmus, 2017, roč. 51, č. 1-2, s. 30-43. ISSN 0044-.8680. 
zachoval v Národnej Széchényiho knižnici v Budapešti. ${ }^{5}$ Plán vytýčil nové ulice, pričom vychádzal z existujúcej uličnej štruktúry a na dovtedy nezastavanom území uplatňoval pravouhlú uličnú siet'. Neustála kritika plánu a odd’al'ovanie jeho schválenia nakoniec vyústili do iniciatívy jedného z významných priemyselníkov a poslancov mesta Johanna Ludwiga zadat' prípravu plánu externe. Ludwig v tejto súvislosti oslovil král'ovského radcu a bývalého komisára Uhorských štátnych dráh Viktora Bernárdta. Jeho plán prezentovali mestskej rade v septembri 1905, ale tiež bezúspešne. ${ }^{6}$ Opakované rokovanie o regulačnom pláne naštartovalo v mestskej rade diskusie o konkrétnych otázkach regulácie, ako bol mestský okruh, regulácia priemyselnej zóny či výstavba druhého mosta cez Dunaj. Práve tieto diskusie nakoniec inšpirovali mestských poslancov $\mathrm{k}$ tomu, aby prípravou plánu poverili v novembri 1906 ozajstného experta. Bol ním v tom čase už známy urbanista a profesor na budapeštianskej Umeleckopriemyselnej škole Antal Palóczi (1849 - 1927). Palóciziho úlohou bolo posúdit' existujúce dva plány, avšak jeho erudovaný komentár pravdepodobne oslovil mestskú radu natol'ko, že už v marci 1907 si u neho objednali vyhotovenie nového plánu regulácie a rozšírenia mesta.

V Novom Sade to bolo podobné. Spracovaním regulačného plánu tiež poverili technické oddelenie mesta pod vedením hlavného inžiniera Rudolfa Stössela. Plán bol vypracovaný na podklade detailnej mapy z roku 1900 a dokončený v roku 1908. Nie je známe, či tento prvý plán ako celok schválili a či ho vôbec verejne prezentovali. Avšak podobne ako v Bratislave, aj v Novom Sade prikročili ešte pred jeho dokončením k obstaraniu plánu v externom prostredí. Na jar v roku 1907 vypísali sút’až na regulačný plán mesta, ktorú vyhodnotili v decembri toho istého roku. V sút'aži na regulačný plán Nového Sadu udelili tri rovnaké ceny týmto autorom: ,Imre Francsek a Lipót Berczeller, Anatl Palóczi a György Kopeczek a nakoniec József Wälder. "7 Všetci ocenení patrili v tom čase k významným uhorským architektom, čo svedčí o váhe, ktorú sút'aži pravdepodobne prikladali v odborných kruhoch. Prípravou regulačného plánu Nového Sadu nakoniec poverili Antala Palócziho.

Pri porovnaní prvých regulačných plánov spracovaných technickými oddeleniami Bratislavy a Nového Sadu môžeme konštatovat', že oba uplatnili vtedajšie princípy plánovania mesta, ako bolo jeho celkové ozdravenie, zlepšenie dopravnej infraštruktúry prostredníctvom nových ulíc vo forme pravouhlej uličnej siete, pomerne mechanicky bez vel'korysejších zásahov do existujúcej mestskej

5 Országos Széchenyi Könyvtár, OSZK TM 422, Pozsony sz. kir. város átnézeti térképe és városbővítési terve, 1906.

6 Stadtregulierung. Pressburger Presse, 25. 09. 1905, roč. 8, č. 400, s. 4.

7 Magyar Mérnök és Építész Egylet Heti Értesítője, 01.12.1907.12.01. 26(43); Épitő Ipar, 01.12.1907. 31(48) 
štruktúry. O tom, ako také plány vnímala odborná verejnost' najlepšie svedčí poznámka bratislavského gymnaziálneho profesora a kustóda mestského múzea Ágosta Helmára, ktorý napísal: ,, V rámci regulačnej práce sa neuplatnilo väčšie mentálne úsilie. ... hlavnou úlohou bolo zbavit'sa každého rohu a každého ostrého záhybu, objavit' priame a rovnobežné línie všade, kde sa len dá. "8

\section{Plánovanie mesta podl’a Antala Palócziho}

Budapeštiansky architekt a urbanista Antal Palóczi venoval od začiatku osemdesiatych rokov 19. storočia vel'kú pozornost' všetkým trendom a princípom teórie moderného plánovania mesta a propagoval tieto myšlienky medzi kolegami v Uhorsku. Vo svojich teoretických prácach sa zaoberal dobovými teóriami, ale aj kritikou urbanistickej praxe. Analyzoval a klasifikoval mestské priestory, pričom vychádzal z práce nemeckého urbanistu Josepha Stübbena. Vo svojej argumentácii však využíval aj princípy, ktoré v odbornej diskusii pomenoval viedenský architekt a urbanista Camillo Sitte. Palóczi, ako jeden z mála v Uhorsku, zdôrazňoval, že najdôležitejším aspektom plánovania mesta nie je výstavba reprezentačných budov, ale konzistentné uplatňovanie celomestského jednotného regulačného plánu. Počas svojej profesionálnej kariéry spracoval množstvo regulačných plánov a bol považovaný za najväššieho experta na urbanizmus $\mathrm{v}$ celom Uhorsku.

V prípade našich dvoch miest, to bola práve Bratislava, kde si mestská rada ako prvá objednala plán regulácie a rozvoja mesta u Antala Palócziho. Prvý náčrt plánu predstavil Palóczi verejnosti v roku 1907. Hned' pri tejto príležitosti ozrejmil svoj prístup k práci, ked' spomenul princípy modernej výstavby miest, ktoré za svoje pravidlá vd’ačia nemeckým hygienickým kongresom, ale aj prístup Camilla Sitteho, ktorému sa vraj „podarilo dostat’ všetkých súčasných urbanistov do svojho tábora “. Vlastnú pozíciu pritom definoval ako „kompromis medzi stredovekými a modernými myšlienkami “, ked” ,pri tvarovaní uličnej siete a spôsobe výstavby... bude reflektovat' moderné nároky, najmä dopravné a hygienické, ale nestratí zo zretel'a ani umelecké nároky a požiadavky komfortu". 9 Palóczi predpokladal, že v najbližších pät'desiatich rokoch sa počet obyvatel'ov Bratislavy zvýši na 150 000, a práve s takou perspektívou pracoval aj v návrhu rozšírenia mesta. Naznačil dva hlavné smery územného rastu. Prvý zahíňal rovinatý terén vtedajších priemyselných predmestí a druhý svahy Malých Karpát na východnom okraji mesta, kde uvažoval s výstavbou záhradnej štvrte. V rámci regulácie navrhoval odstránenie časti železničných tratí z centra, prípadne ich

8 HELMÁR, Ágost: Pozsony és a városépítési elvei a múltban és a jelenben. In Városszabályozási kérdések. Pozsony, Angermayer Ny, s. 29.

9 Prof. Palóczi über die Stadtregulierung. In Pressburger Zeitung, 15. 12. 1908, roč. 145, č. 345, s. 2. 
prestavbu na mimoúrovňové, ako aj zrušenie alebo prestavbu niekol'kých železničných staníc. Súčast'ou jeho plánu bol aj návrh industriálneho kanálu na východnom okraji mesta. Palóczi vo svojom pláne rátal s výstavbou troch nových mostov cez Dunaj, ktoré mali dopravne obslúžit' budúce rozvojové územie na pravom brehu rieky a tranzitnú dopravu. Vel'ký dôraz kládol na morfológiu terénu a jedinečné vlastnosti pôvodnej mestskej štruktúry. Za mimoriadne dôležitý charakteristický znak mesta považoval ruinu hradu, ktorú navrhoval zachovat' $v$ pôvodnej podobe a doplnit' rozsiahlym parkom. K hradu mali smerovat' aj výhlady z hlavných regulovaných alebo novonavrhovaných ulíc a mestských bulvárov. $^{10}$

V tom istom roku, ako bol poverený spracovaním bratislavského plánu, sa Palóczi zúčastnil sút’aže na nový regulačný plán Nového Sadu. Na návrhu spolupracoval s d'alším významným uhorským architektom Györgym Kopeczekom, ktorý navrhol viacero reprezentačných budov aj na území dnešného Slovenska. Po vyhodnotení sút’aže bol spracovaním plánu poverený Antal Palóczi. Na rozpracovaní sútažného návrhu sa podiel'al aj inžinier László Szesztay, ktorý v tom čase pracoval na novom zameraní mesta. Ich regulačný plán posudzovala mestská rada Nového Sadu v januári 1911 a prijala ho, ako základ pre finálnu verziu plánu. ${ }^{11}$ Dobová tlač opisovala plán, ako dokument reflektujúci všetky aktuálne trendy v plánovaní mesta, ako bolo oddel'ovanie jednotlivých funkčne podmienených zón, uplatňovanie princípov hygieny či výstavba dopravných okruhov a mestských radiál. ${ }^{12}$

Ako potenciálny smer rastu mesta plán navrhoval územie pozdĺž toku Dunaja, v miestach kde predpokladal výstavbu nového mostu. Ulica spájajúca centrálne umiestnené námestie Františka Jozefa s novým mostom mala byt' najreprezentačnejšou v meste. ,,V zmysle regulačného plánu mali byt’ pozdľ̌ Dunaja situované najkrajšie parky, verejné budovy, pristav, železničná trat', trhové námestie... a preto mala väčšina dopravy plynút' práve po tejto novonavrhovanej ulici", v dobovej tlači nazývanej „,Ulica Františka Rákocziho “, ktorá mala „, vzhl’adom na svoju širku a stromoradie robit’ na návštevnika mimoriadny dojem ". ${ }^{13} \mathrm{Za}$ ujímavá na tejto komunikačnej osi bola aj skutočnost', že smerom od centra sa postupne rozširovala a mierne menila smer. V zmysle zlepšenia hygienických pomerov v meste, zahŕňal regulačný plán zväčšenie plôch zelene, či už rozšírením existujúcich, alebo zakladaním nových parkov na nezastavaných pozem-

10 Podrobnejšie o Palócziho koncepcii regulácie Bratislavy pozri MORAVČÍKOVÁ - LOVRA - PASTOREKOVÁ, ref. 4.

11 Újvidéki Napló, 15. 11. 1911, roč. 3, č. 3, s. 4.

12 Podrobný opis plánu priniesli noviny Újvidéki Napló v príspevku Újvidék szabályozása és bővítése, 30. 7. 1911, roč. 3, č. 31, s. 1-2.

13 Újvideki Napló, ref. 12. 
koch v centre mesta. Rovnakú úlohu malo plnit' aj narušenie pôvodnej hustej štruktúry otvorením nových námestí a ulíc.

Pri bližšom pohl'ade na proces prípravy plánu regulácie a rozšírenia mesta v prípade Bratislavy a Nového Sadu možno identifikovat' viacero rovnakých postupov. Všimnime si najmä úlohu, ktorú v oboch prípadoch zohralo technické oddelenie mesta, ale aj rozhodnutie poverit' prípravou územnoplánovacej dokumentácie práve Antala Palócziho. Za zmienku stoja aj koncepčné paralely oboch plánov, ktoré sú exemplárnou ukážkou prístupu k plánovaniu a regulácii mesta v prostredí Uhorska na prelome 19. a 20. storočia. Rozhodujúce vtedy bolo určit' budúce smery územného rastu mesta, funkčnú zonáciu mestských plôch, organizáciu cestnej i železničnej dopravy a vytýčenie okružných komunikácií a radiál vrátane situovania premostení, ktoré si mal vyžiadat' budúci rast mesta. Rovnako vážne sa pristupovalo k ozdraveniu mestského prostredia, k návrhu parkov a alejí, ale aj k estetickým stránkam, k tvarovaniu námestí a nových ulíc či k umiestňovaniu reprezentačných budov a pamätníkov. Palóczi v tejto súvislosti uviedol: „Klúč $k$ dobrému pôsobeniu námestia spočiva v jeho vymedzení. Je potrebné vytvorit' súvislý obvod zo stien..., ktorý bude narúšat' len niekol'ko ulíc..., tvar námestia nemusí byt' pravidelný,... rozmery by mali zodpovedat' rozmerom existujúcich budov aj tých, ktoré sa ešte len majú postavit." "14 Na margo reprezentačných budov ešte dodal, že nie je správne sústred'ovat' ich len na jedno miesto. ${ }^{15}$

Antal Palóczi venoval v prípade oboch miest vel'kú pozornost' podrobnej špecifikácii funkcií a spôsobu zástavby jednotlivých častí mesta. Na ploche oboch miest definoval šest' zón, v ktorých sa mal uplatnit' presne určený spôsob výstavby. Zóna, ktorá zahŕňala centrum mesta, mala určenú zástavbu v podobe pevnej uličnej fronty, respektíve uzavretých mestských blokov. Rovnaká kompaktná štruktúra mala byt' zachovaná aj v širšom centre. Smerom k periférii mesta sa forma zástavby postupne uvol'ňovala, najprv do podoby polouzavretých radov až po otvorenú vilovú štruktúru záhradného mesta. Okrajové zóny zahŕňali továrne s robotníckymi obytnými štvrt'ami a pol'nohospodárske plochy s vidieckymi usadlost’ami. Otvorená vilová zástavba s vel'kým podielom zelene mala v oboch mestách obsadit' atraktívne prírodné lokality s dobrým napojením na centrum mesta. V Bratislave to boli karpatské svahy, v Novom Sade bývalé pastviny. Palóczi navrhoval $\mathrm{v}$ oboch mestách usporiadat' dopravu do vnútorného a vonkajšieho okruhu. V prípade Bratislavy taký postup indikoval výstavbu dvoch mostov cez Dunaj. Dopravné problémy malo zmiernit' aj eliminovanie slepých ulíc, rozšírenie existujúcich komunikácií a vytýčenie nových radiál. Pri novozaložených alebo rozšírených uliciach navrhoval Palóczi výsadbu alejí a stro-

14 PALÓCZI, Antal. Pozsony szabad királyi város szabályozásáról. In Városszabályozási kérdések. Pozsony: Angermayer, 1909, s. 10-11.

15 PALÓCZI, Anatal. A mai városépités alapelvei. Budapest: Pátria, 1908, s. 21. 
moradí. „Výsadbou alejí posilňujeme význam ulice, jej komfort, “ konštatoval v jednom zo svojich textov. Súčasne však upozorňoval, že „úspešná výsadba aleje je možná len vtedy, ak je táto vzdialená aspoň 6 metrov od fasády. Ulica, kde by sa mala aleja uplatnit' musí mat' preto minimálnu šírku 24 až 26 metrov “ ${ }^{16}$ Stromoradia a predzáhradky dopĺn̆ali tiež obytné bloky na okraji centra. Palóczi venoval vel'kú pozornost' aj dunajským nábrežiam, ktoré identifikoval ako jedinečné miesta s vel'kým rozvojovým potenciálom, určené na výstavbu reprezentačných budov.

Ďalším pozoruhodným prvkom, ktorý spája plány oboch miest je organizácia industriálnej zóny vrátane zimného prístavu a takzvaného industriálneho kanálu. Industriálny kanál vybudovali v Novom Sade ešte v rokoch 1871 - 1875. V rovnakej podobe sa objavoval aj vo všetkých regulačných plánoch Bratislavy pred rokom 1918. Bratislavský zimný prístav pozostávajúci z dvoch bazénov, ktorý postavili na začiatku 20. storočia ned'aleko najstaršej priemyselnej časti mesta, zase pravdepodobne slúžil ako inšpirácia pre prístav v Novom Sade. Palóczi ho navrhol $\mathrm{v}$ rovnakej podobe a umiestnil ho do vyústenia existujúceho kanálu. V regulačných plánoch oboch miest sa objavujú aj zelené pásy či parky, ktoré boli umiestnené za mestským okruhom, pri industriálnom kanáli alebo ned’aleko priemyselných areálov tak, aby chránili mesto pred exhalátmi.

Za zmienku stojí aj spôsob grafického vyhotovenia plánov. V oboch prípadoch išlo o farebnú kresbu na podklade katastrálnej mapy. Palóczi zobrazil navrhovanú reguláciu modrým atramentom a farebne rozlísil aj jednotlivé zóny s odlišným typom a funkciou zástavby. Práve tieto výkresy spolu s podrobným opisom návrhu od samotného Antala Palócziho slúžili ako podklad pre spracovanie schematických analýz koncepčného riešenia oboch plánov, ktoré ilustrujú tento príspevok.

Antal Palóczi pracoval na regulačnom pláne Bratislavy desat' rokov, pričom ho bol nútený opakovane revidovat', aby zohl'adnil pripomienky mestskej správy a uhorských ministerstiev. Finálnu verziu plánu predstavil na zasadnutí Uhorského zväzu inžinierov a architektov v júni 1917. ${ }^{17}$ Prvý návrh regulačného plánu Nového Sadu dvojice Palóczi - Szesztay pravdepodobne schválili v januári $1911 .{ }^{18}$ Dvojica d'alej pracovala na jeho podrobnejšej verzii, ktorú uverejnili v roku 1912. Zložitý spôsob prerokúvania sprevádzal celý proces prípravy plánov. Významnú úlohu pritom hrali nielen partikulárne záujmy členov mestskej rady, ale aj meniaca sa štátna politika reprezentovaná rozhodnutiami ministerstiev v Budapešti. Pomerne pevné východisko predstavovali aj pôvodné plány

16 PALÓCZI, ref. 15, s. 9.

17 Vortrag Prof. Anton Palóczis über den Stadtregulierungsplan. In Pressburger Zeitung, 17. 6. 1917 , roč. 154 , č. 165 , s. 3 .

18 Újvidéki Napló, 15. 11. 1911, roč. 3, č. 3, s. 4. 
zhotovené technickým oddelením mesta, na ktoré aspoň v základných črtách nadväzovali plány Antala Palócziho. Explicitne túto skutočnost' vyjadrila dobová kritika v súvislosti s regulačným plánom Nového Sadu, ked' konštatovala: „Regulačný plán mesta bol do vel'kej miery navrhnutý v zmysle myšlienok tohto úradu. " ${ }^{19}$ Vstup uznávaného profesora do plánovacieho procesu tak netreba považovat' za revolučné odmietnutie dovtedajších praktík, ale skôr za ich šikovné postupné ovládnutie. Je zrejmé, že Palóczi dokázal citlivo analyzovat' existujúce dokumenty, históriu aj prírodné danosti oboch miest, rovnako ako predpoklady týkajúce sa ich očakávaného rastu. O ne sa potom mohol opierat' pri koncipovaní a argumentácii plánu rozšírenia mesta, riešenia dopravy či zonácie mestskej štruktúry. Za revolučné však rozhodne možno považovat' uplatnenie dvojstupňového plánovacieho mechanizmu, ktorý zahŕňal regulačný plán celého mesta, vrátane rozvojových plôch, a podrobnú reguláciu tých častí mesta, ktoré taký prístup vyžadovali. Antala Palócziho tak možno plným právom považovat' za zakladatel'a moderného mestského plánovania v oboch mestách. Jeho idey súčasne predstavujú pevnú kostru, o ktorú sa vedome či mimovol’ne opieralo aj neskoršie plánovanie oboch miest.

\section{Palócziho idey $\mathbf{v}$ čase}

Regulačné plány Antala Palócziho nestihli v Bratislave ani v Novom Sade schválit' a už vôbec nie v celej šírke uplatnit' vo výstavbe mesta. Podpísali sa pod to najmä historické okolnosti, ako vypuknutie prvej svetovej vojny, následný rozpad monarchie a vznik nových štátnych útvarov, ktorých súčast’ou sa stali aj obe mestá. Svoju úlohu tu však zohrali aj danosti, ako je dlhý časový interval od návrhu po realizáciu a celková zložitost', ktoré sú vlastné plánovaciemu procesu. Napriek tomu možno vplyv Palócziho plánov identifikovat' nielen v neskoršej územnoplánovacej dokumentácii, ale aj vo fyzickej podobe oboch miest.

Po roku 1918 prešla správa miest aj výkon plánovania ich rozvoja a regulácie do rúk novej garnitúry. Pôvodných úradníkov nahradili noví, ktorí mali tendenciu dištancovat' sa od minulej éry. Antal Palóczi bol síce profesionálne aktívny až do svojej smrti v roku 1927, avšak do plánovacieho procesu v Bratislave ani v Novom Sade už nemal príležitost' zasiahnut'. Čast' plánovacej dokumentácie tak ostala uzavretá $\mathrm{v}$ archívoch budapeštianskych ministerstiev, niečo odložili ad acta $\mathrm{v}$ mestských archívoch, ale nezanedbatel'ná čast' stále slúžila ako podklad na reguláciu výstavby. Zákresy budov realizovaných v zmysle pôvodnej regulácie plánovaných novostavieb sa vrstvili v katastrálnych mapách mesta. V Bratislave sa regulácie aj novostavby zakresl'ovali až do zhotovenia novej katastrálnej mapy v roku 1934 do mapového podkladu z roku 1897. V prípade

19 Újvidék szabályozása és bővítése. In Újvidéki Napló, 30. 7. 1911, roč. 3, č. 31. s. 1-2. 
Nového Sadu najvýraznejší vplyv Palócziho názorov na reguláciu a rozšírenie mesta vidiet' na pláne z roku 1929. Technické oddelenie mesta ho spracovalo priamo na podklade pôvodného plánu od Palócziho a Szesztaya, pričom uplatnilo rovnakú štruktúru a členenie mestských blokov aj rovnaké riešenie napojenia zimného prístavu na existujúci industriálny kanál. ${ }^{20}$ Evidentný je však aj podstatný rozdiel týkajúci sa klúčového dopravného riešenia $\mathrm{v}$ podobe mestských okruhov, ktoré v novom pláne nenájdeme. Mestské okruhy tak nakoniec chýbajú aj v aktuálnej podobe mesta.

Zaujímavý obraz poskytuje aj porovnanie súčasnej podoby Bratislavy s Palócziho zámermi. Niektoré z nich, ako bola napríklad myšlienka Priemyselného kanálu, stroskotali ešte pred rozpadom monarchie. Iné zámery, ktoré sa v čase svojho vzniku nestretli takmer so žiadnou reakciou zo strany verejnosti, sa naopak bezvýhradne naplnili. To bol aj prípad Palócziho predstavy o mostných prepojeniach l'avého a pravého dunajského brehu. Všetky aktuálne bratislavské mosty stoja na miestach, ktoré v regulačnom pláne mesta navrhol Antal Palóczi. Naplnili sa však aj jeho predstavy o vedení mestských okruhov, vnútorného aj vonkajšieho. Vedenie železničných tratí, rozmiestnenie železničných staníc a ich kategorizácia sú tiež priamym dôsledkom rozhodnutí opierajúcich sa o predstavy načrtnuté v Palócziho pláne. Vel'mi podobne je na tom aj situovanie univerzitných areálov, ktoré kopíruje všetky tri alternatívy polohy navrhnuté v priebehu rokov 1910 až 1917 Palóczim. Dokonca aj Palócziho predstava o zachovaní hradu, aj ked' nie v ruinóznej podobe, sa nakoniec napriek viacerým zámerom jeho nahradenia vládnou či univerzitnou štvrt’ou naplnila. V pláne regulácie a rozvoja mesta od Antala Palócziho sa dá zretel'ne identifikovat' predobraz viacerých počinov, ktoré v priebehu 20. storočia zásadne ovplyvnili urbanizmus mesta. Palócziho regulačný plán tak možno považovat', napriek tomu, že nebol ako celok nikdy schválený v mestskom zastupitel'stve, nielen za iniciačný, ale aj mienkotvorný v zmysle moderného plánovania mesta. ${ }^{21}$ Pozoruhodné pritom je, že neskorší spracovatelia regulačných, resp. územných plánov mesta sa na pôvodnú výkresovú dokumentáciu ani dobové texty Antala Palócziho spravidla neodvolávali. Ignorovanie historických materiálov bolo pre moderné plánovanie mesta po druhej svetovej vojne charakteristické a malo navodzovat' predstavu o úplne nových originálnych riešeniach. To, že sa aj títo tvorcovia nakoniec dopracovali k rovnakým riešeniam ako ich predchodcovia na začiatku 20. storočia, svedčí o určitej nezámernej kontinuite. Kontinuite vyplývajúcej z prirodzenej vitality a odolnosti mestskej štruktúry, ktorá akoby sama viedla svojich plánovačov k pre ňu najprirodzenejším riešeniam.

20 Biblioteka Matice Srpske, BMS Pg III, 20, Plan grada Novog Sada, Gradski građevinski odeljak.

21 Podrobnejšie pozri MORAVČÍKOVÁ - LOVRA - PASTOREKOVÁ, ref. 4. 
Analýza regulačného plánu Nového Sadu (1908) a Bratislavy (1906), spracovaných technickým oddelením jednotlivých miest

Zdroj: Archív oA HÚ SAV
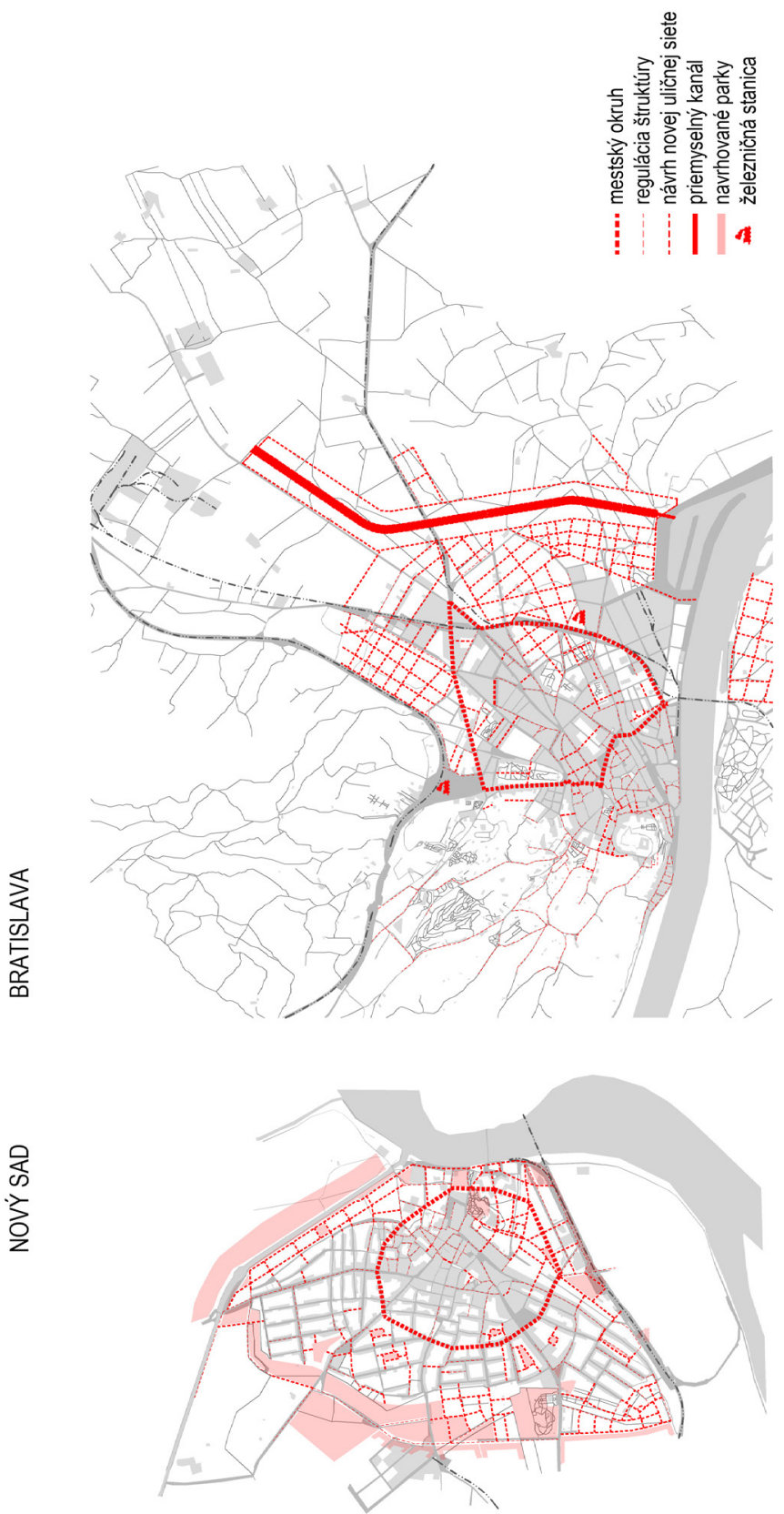


\section{Analýza regulačného plánu Nového Sadu (1910 - 1911) a Bratislavy}

(1907 - 1917) spracovaných Antalom Palóczim

Zdroj: Archív oA HÚ SAV

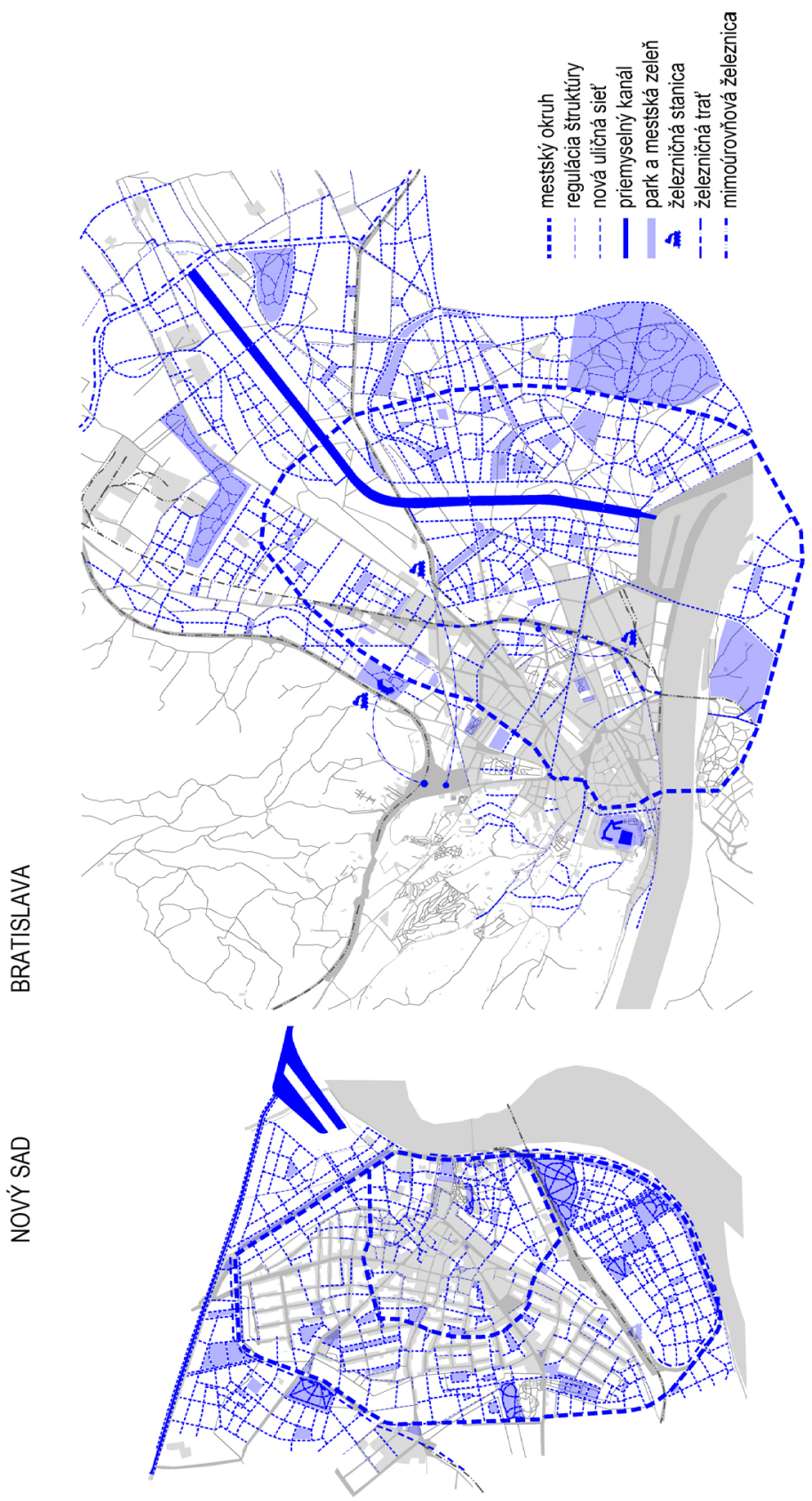


Podobnú vývojovú trajektóriu od prieniku myšlienok moderného plánovania a výstavby miest na sklonku 19. storočia, cez ich vel'korysé naplńanie v podobe prvých regulačných plánov a všeobecnú apropriáciu odbornou aj širšou verejnost'ou v tridsiatych rokoch minulého storočia až po ich takmer úplné prekrytie vrstvou povojnového urbanizmu, možno identifikovat' aj v ostatných mestách niekdajšieho Uhorska. Sondážny výskum historických vrstiev mestského plánovania však ukazuje, že to boli práve pôvodné myšlienky zdiel'ané prvými urbanistami naprieč vtedajšou Európou, ktoré rozhodujúcim spôsobom poznačili podobu našich miest.

* Text vznikol aj vd’aka finančnej podpore agentúry VEGA (projekt č. 2/0074/17 na HÚ SAV a FA STU) a agentúry APVV (projekt č. APVV-16-0584 na HÚ SAV). Výskum Évy Lovra podporili Národný štipendijný program SR (ID 17516) a Nemzet Fiatal Tehetségeiért Ösztöndíj (NTP-NFTÖ-16-0859 a NTP-NFTÖ-17-B-0528).

\title{
ANFÄNGE DER MODERNEN STÄDTEBAULICHEN PLANUNG IN UNGARN: FALL PRESSBURG UND NEUSATZ
}

\author{
HENRIETA M O R AV Č Í K O V Á - ÉVA L O V R A - LAURA \\ K R I Š T E K O V Á
}

Der Zeitraum von 1867 bis 1918 stellt eine der produktivsten Ära der städtebaulichen Planung und Modernisierung der Städte in Ungarn dar. Der Umbau von historischen Strukturen und der Ausbau von neuen Stadtvierteln erreichten ihren Höhepunkt gegen Ende des 19. und am Anfang des 20. Jahrhunderts. Die durch Österreichisch-Ungarischen Ausgleich bedingten gesellschaftlichen und wirtschaftlichen Veränderungen im Jahre 1867 wurden ein leichter Anstoß zur Industrialisierung Ungarns sowie zur Umwandlung der Städte. Die Entwicklung in den ungarischen Städten wurde dabei direkt auch durch den Paradigmenwechsel im Bereich der Stadtplanung beeinflusst. In diesem Zeitraum entstanden neue Bauweisen, es wurden Gebäude von neuen Typologien realisiert und im Allgemeinen sind in die Baugrundsätze der Städte die Ideen einer modernen Planung hineingeraten, wie hygienische Grundsätze, Prinzipien der Zonenabgrenzung und neue Anschauungen über die Verkehrsinfrastruktur. Moderne Prinzipien der städtebaulichen Planung ebenso wie grundlegende Typologie der städtischen Räume (Ringstraße, Boulevard, Promenade, Stadtpark, Gartenviertel usw.) wurden zu einer gemeinsamen Plattform für die Gestaltung der Städte in ganz Ungarn. Diese gemeinsame städtebauliche Sprache war am besten lesbar dort, wo die Pläne in ihrer Komplexität realisiert 
wurden, wie es im Fall Budapest oder Szeged war. Die meisten damaligen Pläne wurden nur teilweise durchgesetzt, beziehungsweise in so fragmentierter Form, dass es heute sehr schwer ist, sie in der Morphologie der Städte zu identifizieren. Hinzu trägt auch die Tatsache bei, dass die Kontinuität der Planung nach dem Zerfall der Monarchie beeinträchtigt wurde und die Pläne aus dem früheren Zeitraum auch in den Nachfolgestaaten oft absichtlich abgewiesen oder ignoriert wurden. Ebenso war auch die Situation in Pressburg und in Neusatz. Die Studie zeigt die Ergebnisse der aktuellen Forschungen, dank denen die bisher unbekannten Dokumente über die Anfänge der modernen Planung dieser beiden Städte entdeckt wurden. Sie konzentriert sich dabei vor allem auf den Beitrag des Urbanisten Antal Palóczi aus Budapest, den Autor der ersten Regulierungsund Entwicklungspläne von Pressburg und Neusatz.

Prof. Dr. Ing. arch. Henrieta Moravčíková

Fakulta architektúry STU, Námestie slobody 17, 81245 Bratislava

Historický ústav SAV, Klemensova 19, 81109 Bratislava

Slovenská republika

e-mail: henrieta.moravcikova@savba.sk

Ing. Éva Lovra, M.Sc., PhD.

Pécsi Tudományegyetem, Müszaki és Informatikai Kar

Boszorkány street 2, 7624 Pécs

Mad'arsko

e-mail: lovra.eva@gmail.com

Ing. arch. Laura Krišteková, PhD.

Historický ústav SAV, Klemensova 19, 81109 Bratislava

Slovenská republika

e-mail: laura.pastorekova@savba.sk 